\title{
Millennials’ Attitudes Toward Online Luxury Buying Behavior in South Korea: A Q-methodology Approach
}

\author{
Regina Burnasheva ${ }^{1}$, Yong GuSuh ${ }^{2} \&$ Katherine Villalobos-Moron ${ }^{3}$ \\ ${ }^{1}$ PhD Candidate, Sookmyung Women's University, Seoul, Republic of Korea \\ 2 Professor of Marketing, Sookmyung Women's University, Seoul, Republic of Korea \\ ${ }^{3}$ Assistant Professor, Namseoul University, Chungnam, Republic of Korea \\ Correspondence: Regina Burnasheva, PhD Candidate, Sookmyung Women's University, Cheongpa-ro 47-gil 100, \\ Seoul, Republic of Korea. Tel: 82-10-3758-9332.
}

Received: September 23, 2018

doi:10.20849/abr.v3i3.512
Accepted: October 16, $2018 \quad$ Online Published: November 28, 2018

URL: https://doi.org/10.20849/abr.v3i3.512

\begin{abstract}
The millennials are a crucial generational cohort of customers who buy luxury goods online. Asian luxury consumers became the major driver of global luxury sales growth. While there are a number of papers from developing countries in Asia, this study explores millennials' attitudes toward shopping online for luxury goods from among the most world's leading economy of South Korea.

This paper has used Q methodology to examine and categorize millennials' behavior toward online luxury consumption. The QUANAL program was employed for data collection and results revealed that there is a significant behavioral distinction between three types of shoppers such as Online Convenience Shopper, Online Economic Shopper and Traditional Shopper.

The findings of this study have a managerial contribution by understanding the typology of online luxury goods consumers among Korean millennials. As one of the sizable cohorts who are purchasing luxury online, this paper could help managers to maintain and increase sales growth among millennials online. This study has also a theoretical or academic contribution by creating a new consumer type and broadening the knowledge about online luxury buying behavior.
\end{abstract}

Keywords: Q methodology, millennials, online luxury buying behavior

\section{Introduction}

The Internet has changed the way of consumers purchasing process and has become an effective tool for businesses. South Korea is the most digitally advanced country having $96 \%$ penetration rate of the internet which is the highest in the world (Pew Research Center, 2017). Moreover, following China and Japan, this is also the third biggest retail e-commerce market in the Asia-Pacific region (eMarketer, 2015), and is the seventh largest worldwide in terms of transaction volume (Statistics Korea, 2017).

Online shopping is becoming a popular method of purchasing, especially among millennials generation (born 1980-2000). In Asia Pacific, according to Accenture (2016), the millennial generation is anticipated to have the biggest purchasing power of any generations ever having a projected disposable income of $\$ 6$ trillion by 2020 . Chinese millennials are the biggest purchasers of luxury goods in Asia Pacific, spending on average US\$4362 annually, followed by South Korea (US\$2638) and Hong Kong (US\$2584) (MasterCard, 2016). Previous studies of millennials' online buying behavior pay attention to developing countries such as India (Swarnakar, Kumar \& Kumar, 2016), China (Acheampong et al., 2016) and Malaysia (Lim, Omar \& Thurasamy, 2015).

Some studies compare the online purchasing attitude between millennials and non-millennials (Generation X). Smith (2015) claims that millennials tend to spend more money than the any other groups in an online shopping despite the fact they don't have much enough income. Millennials are impulsive in their purchasing behavior (Bruseke, 2016) and make decisions very quickly (Lissitsa \& Kol, 2016). They are also inclined to personalized services and customized goods (Ansari \& Mela, 2013). Mangold \& Smith (2012) connotes that millennials have the ability to directly contact suppliers and purchase from them anywhere in the world. On the other hand, the non-millennials' behavior on online shopping is being very meticulous. They look for the detailed information of 
the product before they purchase it. They also care for the reviews of the customers on the social networks. They are loyal to the brand and looking for the accurate benefits of the products (Williams, 2018). Valkama (2015) has emphasized that Generation X is very particular in quality, price and advertising efforts of the firms. One of the limitations of the present paper is that it has focused only on the purchasing behavior of the millennials toward luxury product.

This research is focused on South Korea, because it is among the most leading economy and a digital luxury market in the world. In addition, this study is focused on the millennials' behavior because they have developed different shopping styles compared with previous generations (Bakewell \& Mitchell, 2003) and spending power in online shopping of luxury goods. The aim of this research is to investigate millennials' attitudes toward online luxury buying behavior in South Korea. The two research questions are as follows:

RQ1. How may millennials' attitudes toward online luxury buying behavior in South Korea be typed?

RQ2. How can each type of millennials' attitudes toward online luxury buying behavior in South Korea be characterized?

This research is organized as follows. First, theoretical background in online luxury consumers and typology are provided. Second, Q methodology was used to categorize typologies of millennials' attitudes toward online luxury buying behavior in South Korea. Finally, research findings and implications are discussed.

\section{Theoretical Background}

\subsection{Online Luxury Consumers}

With the digital age in full swing, a number of consumers purchasing online continues to rapidly grow. Nowadays, more and more young consumers prefer online luxury purchases because e-boutiques have distinct advantages such as shopping convenience, diverse product selection, time and price savings, security and privacy.

Previous studies have considered the online luxury consumers behaviors (Liu, Burns \& Hou, 2013; Okonkwo, 2007). Lui, Burns \& Hou (2013) characterized the buyers of online luxury as being mindful of the price and they prefer the availability of products online and have a higher level of reliance on shopper reviews online. Okonkwo (2007) described online luxury consumers as intelligent individuals who are well prepared to look and compare the variety of goods, shopping convenience and effective delivery service considering no extra time cost to directly go to the store. Shoppers of online luxury can be divided into five types such as well-known luxury clients, young \& new clients, clients who just "keep up", young \& aspirational luxury clients and older aspirational clients (Parisi, 2017).

Young consumers as the main clients of online luxury shopping drive the development of luxury e-commerce. Generation $\mathrm{Z}$ and millennials buyers alone have accumulated 85\% growth in the global luxury last 2017 (Bain \& Company, 2017). Millennials is not presently the most profitable group since it is also a new market for luxury brands. However, it is considered as the main customer of the future (Yazici, 2016). In line with this, it is very crucial to pay attention on the behavior. The characteristics of millennial behavior can be described by three major features such as uneasiness, urgency and uniqueness. The first feature refers to the digital communication with peers is on the rise when selecting a good to buy online. While the second feature which is urgency refers to the lesser time in doing a purchase decision with younger customers than doing with older customers. Lastly, the third feature is the uniqueness which denotes that shoppers now look forward to brands that could be aligned with their personal passions and values (Bain \& Company, 2017). The Economist (2014) has forecasted that by 2026, the main consumers of luxury will be millennials. To succeed in a premium market, luxury companies need to understand this generation cohort of consumers. And through the understanding of this generation cohort, luxury companies will be able to build strong digital strategies to reach and keep these consumers.

\subsection{Typology of Online Luxury Consumers}

As discussed earlier, understanding typology of online luxury shoppers is a significant aspect for digital marketing of luxury businesses. Many previous studies have conducted on typology of luxury shoppers from offline perspective (Whang, Yoo \& Chon, 2013; Kim \& Whang, 2009). The MSLGROUP PBJS agency (2015) categorized lifestyles of millennial consumers of luxury goods which includes three distinct types: technophile shoppers, luxury dabblers, and all-access fans. In Korea, Whang, Yoo \& Chon (2013) categorized the luxury shoppers into eight types: self-sufficient, noble type, living type, self-display type, fantasy type, arrogant type, reckless type, and avatar type. Kim \& Whang (2009) categorized the types of luxury consumption into three groups: hedonic consumption, pragmatic consumption, and social consumption. 
However, there is currently limited research on the typology of luxury shoppers related to an online context in South Korea. Nielsen (2000) categorized online consumers into six groups according to their purchasing behaviors: social buyer, a habit buyer, an ethical buyer, a value buyer, an experimental buyer, and a convenience buyer. A huge number of online luxury buyer groups lie within the 'Convenience' and 'Experimental' buyer segments (Okonkwo, 2007).

Shoppers have normally said that their major motivation to utilize Internet shopping is because it is more convenient than in the store (Soopramanien \& Robertson, 2007; Chen, Hsu \& Lin, 2010). Luxury consumers value the variety and availability of the goods that are offered online (Liu, Burns \& Hou, 2013; Quintavalle, 2012) as well as cost and time efficiency (Katawetawaraks \& Wang, 2011; Pham, 2017). On the other hand, shoppers may not be purchasing online because of some potential risks related with Internet shopping including credit card fraud, an absence of touch before buying the product, possible problems with the returned goods (Bhatnagar, Mishra \& Rao, 2000) and not receiving the ordered product (Forsythe \& Shi, 2013; Joines, Scherer $\&$ Scheufele, 2003). For consumers, buying of luxury goods online has raised some concerns, regarding the lack of touch (Kluge \& Fassnacht, 2015; Pappas, 2016), security (Wu, Chen \& Chaney, 2013; Liu, Burns \& Hou, 2013). To understand typology of Korean millennials' attitudes toward online luxury purchasing behavior, this study provides the following three components: 1) attitude; 2) luxury consumption; and 3) online shopping. Many researchers have used self-report methods to segment consumers according to demographic or psychological variables (Belz \& Peattie, 2009), this research uses Q methodology to determine Korean millennials' attitude toward purchasing luxury brands online.

\section{Research Method}

\subsection{Q Methodology}

The Q methodology is a powerful method for determining attitudes around controversial topics where it is hard to measure people's opinions (Barry \& Proops, 1999). The Q methodology has been used, in previous studies of offline environments, to investigate various attitudes towards luxury consumption (Whang, Yoo \& Chon, 2013), sustainable fashion (Song \& Ko, 2016), global fashion counterfeits (Lee et al., 2015) and under online environments, to analyze different types of online personas (Dang-Pham, Pittayachawan \& Nkhoma, 2015), Internet users' participation (Previte, Hearn \& Dann, 2001). This study is based on Q methodology to examine and categorize Korean millennials' attitudes toward online luxury purchasing behavior.

Q methodological research consists of 5 stages: 1) develop of a Q sample, 2) identify of the study population, 3) conduct data collection, 4) perform data analysis, and 5) interpret factor identities (Baxter \& Hacking, 2015).

\subsection{Q Sample}

One of the first and most important stages in Q methodology is to develop of a Q sample (concourse). Concourse is a methodological idea to gather data like probable statements of the participants could have on a particular issue (Sulphey, 2014), which is pared down to outline the Q-set that respondents will rank the order in the period of Q-sort (Stephenson, 1978). A number of items in a Q set could fall between 20 and 100 statements (Watts \& Stenner, 2012), but it typically consists of 20 to 50 statements, which will be required to rank by 7-11 pile (Mrtek, Tafesse \&Wigger, 1996). In this study, 83 statements were initially gathered from scholarly articles, the Internet, books and then narrowed to 30 statements. Combining identical statements and removing duplicates are done to administer this. To obtain comprehensiveness of a Q sample, a preliminary Q-set was organized in Sookmyung University and it involved 8 students to revise the statements. Finally, 23 statements were selected, which sorted into three themes: attitude, luxury consumption and online shopping. Table 1 shows the list of the final set of statements. 
Table 1. Q samples

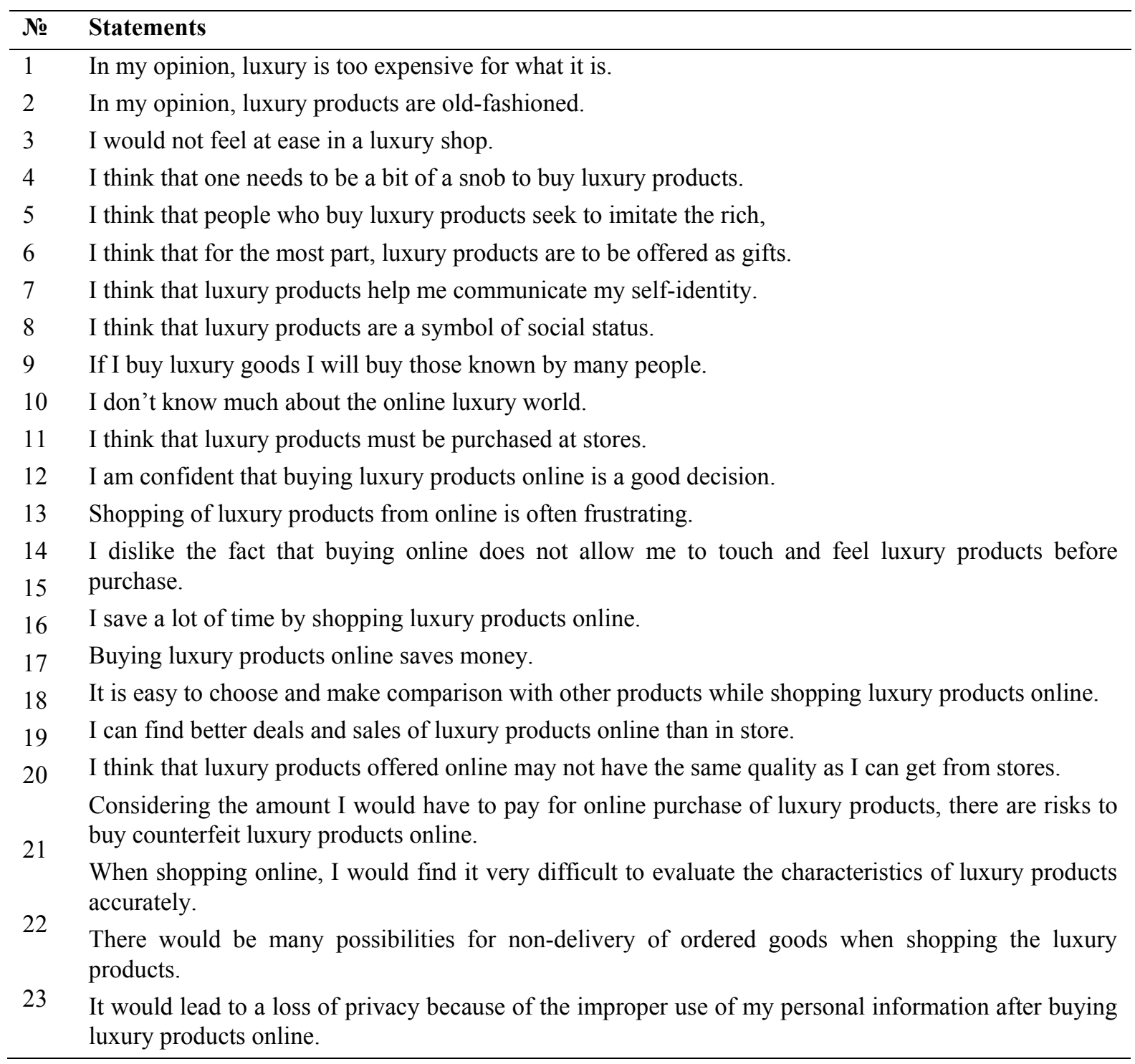

\subsection{P Sample}

The strength of the Q method is that it collaborates both aspects of qualitative and quantitative research and it is empirically robust even with small samples (Minkman, Rutten \& van der Sanden, 2016), usually 20-60 participants (Brown, 1980), and the main concept of this approach is to reveal and identify the different subjective positions, rather than making any findings on their relative occurrence (McKeown \& Thomas, 1988). Due to a smaller number of respondents, it is more likely that there will be no problems with comprehensiveness, diversity (Eden, Donaldson \& Walker, 2005), quality and consistency (Raje, 2007). In this study, thirty millennials from Korea were asked to fill a Q sample from May to June 2018. Out of the thirty participants, twenty-eight provided usable responses, where eighteen (64.3\%) were women and ten $(35.7 \%)$ were men, with an age range from 18 to 38 years. Most of the participants were well educated with $71.4 \%$ of them have undergraduate degree. The findings also show that a majority of them were students $(60.7 \%)$, then employees $(28.6 \%)$, and businesspersons (10.7\%). Table 2 presents the demographic profile of the participants. 
Table 2. The demographic profile of the participants

\begin{tabular}{lll}
\hline Category & Frequency & Percentage \\
\hline Gender & 10 & $35.7 \%$ \\
Male & 18 & $64.3 \%$ \\
Female & & \\
Education & 1 & $3.6 \%$ \\
High school & 20 & $71.4 \%$ \\
Undergrad. degree & 7 & $25 \%$ \\
Graduate degree & & \\
Occupation & 17 & $60.7 \%$ \\
Student & 3 & $10.7 \%$ \\
Businessperson & 8 & $28.6 \%$ \\
Employee & & \\
\hline
\end{tabular}

\subsection{Q Sorting}

The foundation of $\mathrm{Q}$ methodology is the $\mathrm{Q}$ sort technique, which is administered by $\mathrm{Q}$ factor analysis (Brown, 1980). The Q sort is a procedure by which the participants categorize the Q statements and give a grade to each statement (Kim \& Shin, 2017) according to the agreement or disagreement. Q sorting takes about 30 minutes and starts with a subject's introduction of the study and then guide the participants with information about classifying of the set of statements. Q statements are written onto cards and participants are requested to read and arrange these cards into 3 random pile: those respondents most agreed with, those they most disagreed with and those that they had no opinion on or are neutral about (Raje, 2007; Deogaonkar et al., 2016). After participants ranked all items, they should decide the statistical value (from -3 to +3 ) using quasi-normal distribution of a seven-point Likert scale shown in Figure 1. Additionally, items with the highest rankings $(+3)$ and those with the lowest rankings (-3) were asked for better understanding. The outcome of the sorting method is a forced decision-making procedure, where the respondents must come to a decision amongst the statements and generate a result to show their decisions (Cottle \& McKeown, 1980).

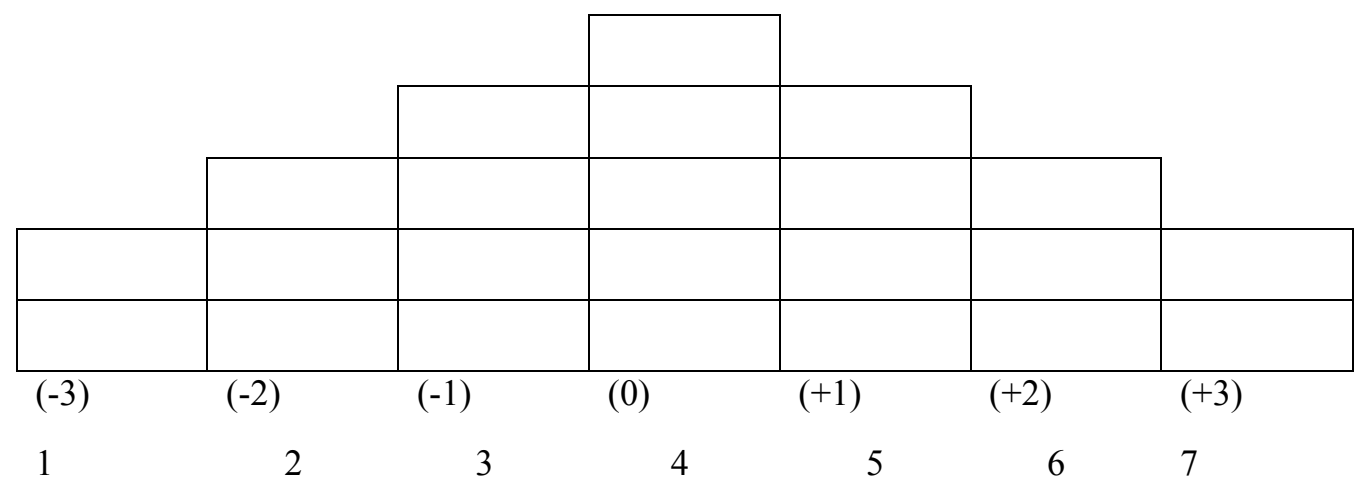

Figure 1. The Q-grid (seven-level quasi-normal distribution)

\section{Data Analysis and Results}

\subsection{Data Analysis}

Collected data were analyzed through the QUANAL program for principal component analysis using VARIMAX rotation. Each Q sort had mean of 4, with a standard deviation of 1.7195. A three-factor solution has showed to have the best outcomes among those determined by inputting a range of factor solutions through the criteria of total variance and eigenvalues (Kim, 2017). Both high value of eigenvalues and variance are 
connected with a solid theoretical background for the study (Watts \& Stenner, 2012). As a rule of thumb, variables with Eigenvalues higher than 1 are statistically significant while those Eigenvalues with lesser value are not (Brown, 2004). The eigenvalue of this study was above 1, demonstrating significant results among three distinct types: Type 1 had 8.23 eigenvalue with 29 percent of the total variance; Type 2 had 3.03 eigenvalue with 11 percent of the total variance and Type 3 had 2.08 eigenvalue with 7 percent of the total variance. According to the Watts \& Stenner (2012) total variance explained by the Q-sorts should be higher than $35 \%$ and this supports that all results of present study were acceptable with $47 \%$ variance explained.

The initial analysis of the Q sorts is essentially a correlation using factor analysis (Ramlo, 2015), revealing sorting similarities and differences between factors (Watts \& Stenner, 2014). As shown in Table 3, there is a relatively high correlation among three types, which indicates that they are interrelated. Types 1 and 3 showed a high correlation results in the amount of 0.522 and that a correlation between Types 2 and 3 is 0.442 . Type 1, on the other hand, showed a weaker correlation with Type $2(0.371)$.

Table 3. Correlation matrix between types

\begin{tabular}{cccc}
\hline Type & Type 1 & Type 2 & Type3 \\
\hline Type 1 & 1.00 & & \\
Type 2 & 0.371 & 1.00 & \\
Type3 & 0.522 & 0.442 & 1.00 \\
\hline
\end{tabular}

Q methodology inverts variable analysis through grouping participants' Q-sorts, thus representing underlying shared perceptions (Brown, 1996). Out of 28 respondents, 9 respondents belonged to Factor 1, 6 to Factor 2, and 13 to Factor3, which means that respondents can be divided into 3 distinct types according to view points. The factor analysis' interpretation is depending on factor scores. A statement's factor score is the normalized weighted average statement score which is also termed as Z-score of participants that describe that variable (Van Exel \& de Graaf, 2005). To investigate the distinction between types, the most agree (a standard score $>+1.0$ ) and the most disagree (standard score $<-1.0$ ) statements were used for analysis. Table 4 presents the statement scores and description for each type.

Table 4. Statement scores for each type

\begin{tabular}{|c|c|c|c|}
\hline Group & Statement & Description & $\begin{array}{l}\text { Standard } \\
\text { Score }\end{array}$ \\
\hline \multirow{8}{*}{$\begin{array}{l}\text { Type 1: Online } \\
\text { Convenience } \\
\text { Shopper }(n=9)\end{array}$} & 18 & $\begin{array}{l}\text { I can find better deals and sales of luxury products online than } \\
\text { in store. }\end{array}$ & 1.78 \\
\hline & 17 & $\begin{array}{l}\text { It is easy to choose and make comparison with other products } \\
\text { while shopping luxury products online. }\end{array}$ & 1.66 \\
\hline & \multirow[t]{2}{*}{20} & $\begin{array}{l}\text { Considering the amount I would have to pay for online } \\
\text { purchase of luxury products, there are risks to buy counterfeit } \\
\text { luxury products online. }\end{array}$ & \multirow[t]{2}{*}{1.51} \\
\hline & & I save a lot of time by shopping luxury products online. & \\
\hline & 15 & If I buy luxury goods I will buy those known by many people. & 1.09 \\
\hline & 9 & \multirow{2}{*}{$\begin{array}{l}\text { I think that people who buy luxury products seek to imitate the } \\
\text { rich. }\end{array}$} & -1.49 \\
\hline & 5 & & -1.54 \\
\hline & 4 & $\begin{array}{l}\text { I think that one needs to be a bit of a snob to buy luxury } \\
\text { products. }\end{array}$ & -1.83 \\
\hline \multirow{4}{*}{$\begin{array}{l}\text { Type 2: Online } \\
\text { Economic }\end{array}$} & 1 & In my opinion, luxury is too expensive for what it is. & 1.97 \\
\hline & 18 & $\begin{array}{l}\text { I can find better deals and sales of luxury products online than } \\
\text { in store. }\end{array}$ & 1.64 \\
\hline & \multirow[t]{2}{*}{16} & Buying luxury products online saves me money. & \multirow{2}{*}{1.23} \\
\hline & & I save a lot of time by shopping luxury products online. & \\
\hline
\end{tabular}




\begin{tabular}{|c|c|c|c|}
\hline \multirow[t]{6}{*}{ Shopper $(n=6)$} & $\begin{array}{r}15 \\
6\end{array}$ & $\begin{array}{l}\text { I think that for the most part, luxury products are to be offered } \\
\text { as gifts. }\end{array}$ & $\begin{array}{r}1.01 \\
-1.16\end{array}$ \\
\hline & 20 & $\begin{array}{l}\text { There would be many possibilities for non-delivery of ordered } \\
\text { goods when shopping the luxury products. }\end{array}$ & 14 \\
\hline & & $\begin{array}{l}\text { It would lead to a loss of privacy because of improper use of } \\
\text { my personal information after buying luxury products online. }\end{array}$ & -1.40 \\
\hline & 23 & In my opinion, luxury products are old-fashioned. & -1.46 \\
\hline & 2 & Shopping of luxury products from online is often frustrating. & -1.48 \\
\hline & 13 & & -1.71 \\
\hline \multirow{10}{*}{$\begin{array}{c}\text { Type 3: } \\
\text { Traditional } \\
\text { Shopper }(n=13)\end{array}$} & 7 & $\begin{array}{l}\text { I think that luxury products help me communicate my own } \\
\text { self-identity. }\end{array}$ & 1.48 \\
\hline & 14 & $\begin{array}{l}\text { I dislike the fact that buying online does not allow me to touch } \\
\text { and feel luxury products before purchase. }\end{array}$ & 1.40 \\
\hline & 9 & If I buy luxury goods I will buy those known by many people. & 1.26 \\
\hline & 1 & In my opinion, luxury is too expensive for what it is. & 1.24 \\
\hline & 4 & $\begin{array}{l}\text { I think that one needs to be a bit of a snob to buy luxury } \\
\text { products. }\end{array}$ & -1.25 \\
\hline & 22 & $\begin{array}{l}\text { There would be many possibilities for non-delivery of ordered } \\
\text { goods when shopping luxury products. }\end{array}$ & -1.40 \\
\hline & 6 & $\begin{array}{l}\text { I think that for the most part, luxury products are to be offered } \\
\text { as gifts. }\end{array}$ & -1.47 \\
\hline & & In my opinion, luxury products are old-fashioned. & \\
\hline & 2 & I think that people who buy luxury products seek to imitate the & -1.85 \\
\hline & 5 & rich. & -1.90 \\
\hline
\end{tabular}

\subsection{Results}

The results demonstrate that there are three distinct types of attitudes toward shopping online for luxury goods: Online Advocate Shopper, Online Economic Shopper and Traditional in-store Shopper.

\subsubsection{Online Convenience Shopper}

Type 1 was the 'online convenience shopper,' consisting of nine participants, including 6 women and 3 men. The respondents in this type prefer purchasing online, because they think that shopping online suggests convenience benefits such as saving money, saving time and ease to choosing and making comparison with other products. Shoppers in this type look out for better deals and sales and enjoy getting the best deal. They also like to choose and make comparison with other products online without extra save cost. Overall, the first type of shoppers is highly positive about online shopping and they receive many advantages from it, but at the same time they are aware of negative aspects such as risks to buy counterfeit luxury products online.

On the other hand, they avoid well-known luxury products and buy unique products to express their personality. And they don't think that people need to be a bit of snob or imitate the rich to buy luxury products.

In brief, the convenience aspect has stimulated the online shopping experience of the online convenience shoppers.

\subsubsection{Online Economic Shopper}

Type 2 was the 'online economic shopper,' consisting of six participants, including 3 women and 3 men. They are similar to online convenience shoppers in that they think shopping online suggests convenience benefits such as saving money and saving time but they consider money as the most valuable factor. They purchase luxury product online if it has a fair and reasonable price and they feel good when finding the best deals and sales. They see those deals and sales as a chance to save money. Similar to online convenience shoppers, they also focus on the time- saving aspect, but they don't feel risk in purchasing luxury products online. These shoppers trust in online shopping and they are not worried about delivery of ordered products and loss of privacy after buying 
luxury products online. Moreover, they think that luxury is modern, too expensive and for the most part, luxury products are not to be offered as a gift.

In general, online economic shoppers have a positive attitude towards online shopping and consider it enjoyable with many benefits such as money and time savings.

\subsubsection{Traditional Shopper}

Traditional shopper had the largest number of participants $(n=13)$ with nine women and 4 men. Unlike online convenience shopper and online economic shopper, they prefer traditional shopping, because they want to physically see, feel and touch a luxury product. They are afraid to buy counterfeit and consider quality as the most valuable attribute. They prefer well-known luxury products and assume that luxury is a meaningful presentation of self-identity. Similar to online convenience shoppers, they don't think that people need to be a bit of snob or imitate the rich to buy luxury products. In addition, traditional shoppers, as compared with the online economic shoppers, think that luxury is modern, too expensive and for the most part, luxury products are not to be offered as a gift.

In summary, the traditional shoppers are positive about purchasing in store and they wish to physically see, feel and touch luxury products.

To evaluate the differences between each type, this research compares an array of both types. The Table 5 below shows the array of differences of each type. Type 1 and Type 2 are not worried about delivery of ordered goods, but they are concerned about purchasing counterfeit online. In addition, Type 1 fears for the security of their personal information after buying luxury products online. In general, both groups trust in online shopping, whereas Type 1 is a more sensitive risk group. Moreover, both types enjoy choosing and comparing with other products, whereas Type 1 is more engaging with comparison-shopping, while Type 2 is more frugal with money.

Type 1, as compared with the Type 3, finds more benefits of online shopping such as better deals and sales, convenience to choose and make comparison with other products and excellence of delivery. But Type 3 on the other hand seems to value traditional shopping and considers the advantages such as better deals and sales in store, an opportunity to touch and feel products. Moreover, Type 3 prefers well-known products to show their social class.

Compared to the Type 2, Type 3 is not familiar with online shopping and does not know much about the online luxury world. Moreover, they consider it very hard to determine the features of luxury goods and to get better offers and discounts online than in store. Both groups consider luxury as an indicator of self-identity. However, Type 2 believes that people seek to imitate rich and require to be a little snob to acquire some luxury goods.

Table 5. Differences between each type

\begin{tabular}{|c|c|c|c|c|c|}
\hline & \multirow[b]{2}{*}{ Statements } & \multirow[b]{2}{*}{ Description } & \multicolumn{3}{|c|}{ Score } \\
\hline & & & Type 1 & Type 2 & Difference \\
\hline \multirow{6}{*}{$\begin{array}{l}\text { Type } 1 \\
\text { and } \\
\text { Type } 2\end{array}$} & 23 & $\begin{array}{l}\text { It would lead to a loss of privacy because of } \\
\text { the improper use of my personal information } \\
\text { after buying luxury products online. }\end{array}$ & 0.122 & -1.465 & 1.587 \\
\hline & 20 & $\begin{array}{l}\text { Considering the amount I would have to pay } \\
\text { for online purchase of luxury products, there } \\
\text { are risks to buy counterfeit luxury products } \\
\text { online. }\end{array}$ & 1.511 & 0.147 & 1.364 \\
\hline & 22 & $\begin{array}{l}\text { There would be many possibilities for } \\
\text { non-delivery of ordered goods when } \\
\text { shopping the luxury products }\end{array}$ & -0.257 & -1.460 & 1.203 \\
\hline & 17 & $\begin{array}{l}\text { It is easy to choose and make comparison } \\
\text { with other products while shopping luxury } \\
\text { products online. }\end{array}$ & 1.664 & 0.485 & 1.179 \\
\hline & & $\begin{array}{l}\text { I think that people who buy luxury products } \\
\text { seek to imitate the rich. }\end{array}$ & & & \\
\hline & 5 & $\begin{array}{l}\text { In my opinion, luxury is too expensive for } \\
\text { what it is. }\end{array}$ & -1.542 & 0.331 & -1.873 \\
\hline
\end{tabular}




\begin{tabular}{|c|c|c|c|c|c|}
\hline & 1 & $\begin{array}{l}\text { I think that one needs to be a bit of a snob to } \\
\text { buy luxury products. }\end{array}$ & -0.102 & 1.971 & -2.073 \\
\hline & 4 & & -1.833 & 0.781 & -2.614 \\
\hline \multirow{6}{*}{$\begin{array}{c}\text { Type } 1 \\
\text { and } \\
\text { Type } 3\end{array}$} & 18 & $\begin{array}{l}\text { I can find better deals and sales of luxury } \\
\text { products online than in store. }\end{array}$ & 1.775 & -0.054 & 1.829 \\
\hline & 17 & $\begin{array}{l}\text { It is easy to choose and make comparison } \\
\text { with other products online. }\end{array}$ & 1.664 & 0.214 & 1.449 \\
\hline & 22 & $\begin{array}{l}\text { There would be many possibilities for } \\
\text { non-delivery of ordered goods. }\end{array}$ & -0.257 & -1.396 & 1.139 \\
\hline & 14 & $\begin{array}{l}\text { I dislike the fact that buying online does not } \\
\text { allow me to touch and feel products. }\end{array}$ & 0.378 & 1.396 & -1.018 \\
\hline & 1 & $\begin{array}{l}\text { In my opinion, luxury is too expensive for } \\
\text { what it is. }\end{array}$ & -0.102 & 1.238 & -1.340 \\
\hline & 9 & $\begin{array}{l}\text { If I buy luxury goods I will buy those } \\
\text { known by many people. }\end{array}$ & -1.489 & 1.262 & -2.751 \\
\hline \multirow{7}{*}{$\begin{array}{c}\text { Type } 2 \\
\text { and } \\
\text { Type } 3\end{array}$} & 5 & $\begin{array}{l}\text { I think that people who buy luxury products } \\
\text { seek to imitate the rich. }\end{array}$ & 0.331 & -1.904 & 2.235 \\
\hline & 4 & $\begin{array}{l}\text { I think that one needs to be a bit of a snob to } \\
\text { buy luxury products. }\end{array}$ & 0.781 & -1.248 & 2.029 \\
\hline & 18 & $\begin{array}{l}\text { I can find better deals and sales of luxury } \\
\text { products online than in store. }\end{array}$ & 1.639 & -0.054 & 1.693 \\
\hline & 10 & $\begin{array}{l}\text { I don't know much about the online luxury } \\
\text { world. }\end{array}$ & -0.839 & 0.395 & -1.234 \\
\hline & 7 & $\begin{array}{l}\text { I think that luxury products help me } \\
\text { communicate my self-identity. }\end{array}$ & 0.227 & 1.476 & -1.249 \\
\hline & 21 & $\begin{array}{l}\text { When shopping online, I would find it very } \\
\text { difficult to evaluate characteristics of the } \\
\text { luxury products. }\end{array}$ & 0.375 & 0.877 & -1.252 \\
\hline & 13 & $\begin{array}{l}\text { Shopping of luxury products from online is } \\
\text { always frustrating. }\end{array}$ & -1.710 & -0.334 & -1.376 \\
\hline
\end{tabular}

\section{Conclusion}

This study investigated the millennials' attitudes toward online luxury buying behavior in South Korea using Q methodology and developed three distinct types: online convenience shopper (Type 1), online economic shopper (Type 2), and traditional shopper (Type 3). Online convenience shoppers have positive attitudes toward purchasing luxury online and consider convenience as the most important aspect. Online economic shoppers also prefer to purchase online, but for a different motive. Instead of considering convenience as the main aspect, these shoppers placed considerable emphasis on price. On the other hand, traditional shoppers enjoy shopping in-store, because they like to physically see, feel and touch a luxury product.

Although there are many previous studies investigated typologies of shoppers from an online perspective (Nielsen, 2000; Rohm \& Swaminathan, 2004; Jayawardhena, Wright \& Dennis, 2007; Barnes et al., 2007; Keng Kau, Tang \& Ghose, 2003; Ganesh et al., 2010), there is a scarcity of studies exploring typologies of online luxury shoppers in South Korea. The findings of this study will make an essential contribution to the body of literature in the field of luxury by broadening knowledge and offering new insights about typologies of millennials' attitudes toward online luxury buying behavior in South Korea. In addition, from a managerial aspect, the findings of this study will help the luxury brand companies to understand millennials' online luxury buying behavior in South Korea and how to better reach and maintain customers from this generation. 
The current research has the following limitations and future directions: First, samples conducted in this research were limited to millennial generations in South Korea. However, in order to gain a better understanding of attitudes towards online luxury buying behavior, future studies should target different generational groups in other countries. Second, this study was based on Q methodology with a small sample and it is considered as one of its limitations and for further research, inclusion of a larger survey having a more representative sample size using a mixed method approach should be done. Finally, the present study consisted only of 23 statements within three components. Future researchers should include more statements within different components in order to provide a comprehensive insight of millennials' attitudes toward online luxury buying behavior in South Korea.

\section{References}

Accenture. (2016). Retailers and Consumer packaged goods companies must enhance their understanding of millennial consumers to capture share of Wallet in Asia. Retrieved 6 September, 2016, from https://newsroom.accenture.com/news/retailers-and-consumer-packaged-goods-companies-must-enhance-th eir-understanding-of-millennial-consumers-to-capture-share-of-6trillion-wallet-in-asia-accenture-warns.htm

Acheampong, P., Zhiwen, L., Abubakar, R., Antwi, H., \& Akomeah, O. (2016). Stimulants of online shopping behaviour among Chinese millennials in China. International Journal of Academic Research in Business and Social Sciences, 6(5), 331-349. https://doi.org/10.6007/ijarbss/v6-i5/2152

Ansari, A., \& Mela, C. F. (2003). E-Customization. Journal of Marketing Research, 40(2), 131-145. https://doi.org/10.1509/jmkr.40.2.131.19224

Bain \& Company and Farfetch. (2017). The millennial state of mind: Digital is reshaping how luxury is purchased across generations. from http://www.bain.de/Images/BAIN\%20MEDIA\%20PACK_The_Millennial_State_of_Mind.pdf

Bain \& Company. (2017, Oct.). Luxury goods worldwide market study. Millennial state of mind: the tailwind behind consumer behaviors and winning strategies. Claudia d'Arpizio \& Federica Levato. Retrieved from http://www.bain.com/publications/articles/luxury-goods-worldwide-market-study-fall-winter-2017.aspx

Bakewell, C., \& Mitchell, V. (2003). Generation Y female consumer decision-making styles. International Journal of Retail \& Distribution Management, 31(2), 95-106. https://doi.org/10.1108/09590550310461994

Barnes, S., Bauer, H., Neumann, M., \& Huber, F. (2007). Segmenting cyberspace: a customer typology of the internet. European Journal of Marketing, 41(1/2), 71-93. https://doi.org/10.1108/03090560710718120

Barry, J., \& Proops, J. (1999). Seeking sustainability discourses with Q methodology. Ecological Economics, 28(3), 337-345. https://doi.org/10.1016/s0921-8009(98)00053-6

Baxter, J., \& Hacking, N. (2015). Expert hydrogen perspectives for technological innovation: A Q-method study. International Journal Hydrogen Energy, 40(8), 3111-3121. https://doi.org/10.1016/j.ijhydene.2014.06.171

Belz, F., \& Peattie, K. (2009). Sustainability marketing. New York: John Wiley \& Sons Inc.

Bhatnagar, A., Misra, S., \& Rao, H. (2000). On risk, convenience, and Internet shopping behavior. Communications of the ACM, 43(11), 98-105. https://doi.org/10.1145/353360.353371

Brown, M. (2004). Illuminating patterns of perception: An overview of $Q$ methodology. Ft. Belvoir: Defense Technical Information Center.

Brown, S. (1980). Political subjectivity: Applications of $Q$ methodology in political science. London: Yale University Press.

Brown, S. (1996). Q methodology and qualitative research. Qualitative Health Research, 6(4), 561-567. https://doi.org/10.1177/104973239600600408

Bruseke, L. (2016). The influence of privacy perceptions on online shopping behavior - a comparison between millennials and baby boomers. Paper presented to the $7^{\text {th }}$ IBA Bachelor Thesis Conference, Enschede, The Netherlands. Retrieved from https://essay.utwente.nl/70179/1/Brueseke_BA_BMS.pdf

Chen, Y., Hsu, I., \& Lin, C. (2010). Website attributes that increase consumer purchase intention: A conjoint analysis. Journal of Business Research, 63(9-10), 1007-1014. https://doi.org/10.1016/j.jbusres.2009.01.023

Cottle, C., \& McKeown, B. (1980). The forced-free distinction in Q-Technique: a note on unused categories in the Q sort continuum. Operant subjectivity, 3, 58-63. https://doi.org/10.15133/j.os.1980.003 
Dang-Pham, D., Pittayachawan, S., \& Nkhoma, M. (2015). Demystifying online personas of Vietnamese young adults on Facebook: A Q-methodology approach. Australian Journal of Information Systems, 19, 1-22. https://doi.org/10.3127/ajis.v19i0.1204

Deogaonkar, R., Baker, R., Mason, H., McHugh, N., \& Collins M. (2016). Eliciting societal views on the value of life-extending treatments using Q methodology. In Round J. (Ed.), Care at the End of Life (pp. 141-152). Adis, Cham. https://doi.org/10.1007/978-3-319-28267-1_10

Eden, S., Donaldson, A., \& Walker, G. (2005). Structuring subjectivities? Using Q methodology in human geography. Area, 37(4), 413-422. https://doi.org/10.1111/j.1475-4762.2005.00641.x

eMarketer. (2015, Jan.). Retail sales worldwide will top \$22 trillion this year, 2014. Retrieved 23 December, 2014, https://www.emarketer.com/Article/Retail-Sales-Worldwide-Will-Top-22-Trillion-This-Year/1011765

Forsythe, S., \& Shi, B. (2003). Consumer patronage and risk perceptions in Internet shopping. Journal of Business Research, 56(11), 867-875. https://doi.org/10.1016/s0148-2963(01)00273-9

Ganesh, J., Reynolds, K., Luckett, M., \& Pomirleanu, N. (2010). Online shopper motivations, and e-store attributes: An examination of online patronage behavior and shopper typologies. Journal of Retailing, 86(1), 106-115. https://doi.org/10.1016/j.jretai.2010.01.003

Jayawardhena, C., Tiu Wright, L., \& Dennis, C. (2007). Consumers Online: Intentions, orientations and segmentation. International Journal of Retail \& Distribution Management, 35(6), 515-26. https://doi.org/10.1108/09590550710750377

Joines, J., Scherer, C., \& Scheufele, D. (2003). Exploring the motivations for consumer Web use and their implications for e-commerce. Journal of Consumer Marketing, 20(2), 90-108. https://doi.org/10.1108/07363760310464578

Katawetawaraks, C., \& Wang, C. (2011). Online shopper behavior: Influences of online shopping decision. Asian Journal of Business Research, 1(2), 66-74. https://doi.org/10.14707/ajbr.110012

Keng Kau, A., Tang, Y., \& Ghose, S. (2003). Typology of Online Shoppers. Journal of Consumer Marketing, 20(2), 139-56. https://doi.org/10.1108/07363760310464604

Kim, A. (2017). Acceptance of complementary and alternative therapy among nurses: A Q-methodological study. Korea Journal of Adult Nursing, 29(4), 441-449. https://doi.org/10.7475/kjan.2017.29.4.441

Kim, J. Y., \& Whang, S. M. (2009). A study on the types and the characteristics of luxury consumption in Korean society. Journal of KSSSS, 19, 43-59.

Kim, N. D. (2007). Luxury Korea: The country of extravagances. Seoul: Miraebook Publishing.

Kim, T., \& Shin, D. (2017). The survival strategy of branded content in the over-the-top (OTT) environment: Eye-tracking and Q methodology approach in digital product placement. Telematics and Informatics, 34(7), 1081-1092. https://doi.org/10.1016/j.tele.2017.04.016

Kluge, P., \& Fassnacht, M. (2015). Selling luxury goods online: Effects of online accessibility and price display. International Journal of Retail \& Distribution Management, 43(10/11), 1065-1082. https://doi.org/10.1108/ijrdm-07-2014-0097

Lee, S., Jung, K., Eun, J., \& Workman, J.E. (2015). What do consumers think about widespread fashion counterfeits? A Q-methodological analysis of the diverse viewpoints. International textile and Apparel Association Annual Conference Proceedings, 59.

Lim, Y., Omar, A., \& Thurasamy, R. (2015). Online Purchase: A Study of Generation Y in Malaysia. International Journal of Business and Management, 10(6). 1-7. https://doi.org/10.5539/ijbm.v10n6p298

Lissitsa, S., \& Kol, O. (2016). Generation X vs. Generation Y - A decade of online shopping. Journal of Retailing and Consumer Services, 304-312. https://doi.org/10.1016/j.jretconser.2016.04.015

Liu, X., Burns, A., \& Hou, Y. (2013). Comparing online and in-store shopping behavior towards luxury goods. International Journal of Retail \& Distribution Management, 41(11/12), 885-900. https://doi.org/10.1108/ijrdm-01-2013-0018

Mangold, W. G., \& Smith, K. T. (2012). Selling to Millennials with online reviews. Business Horizons, 55(2), 141-153. https://doi.org/10.1016/j.bushor.2011.11.001 
Mastercard. (2015, Sep.). Millennials in China looking to spend nearly double the Asia Pacific average on luxury items in the next year. Retrieved 6 October, 2016, from http://newsroom.mastercard.com/asia-pacific/press-releases/millennials-in-asia-pacific/press-releases/millen nials-in-china-looking-to-spend-nearly-double-the-asia-pacific-average-on-luxury-items-in-the-next-year/

McKeown, B., \& Thomas, D. (1988). Q methodology. Sage publications, Series University paper, USA, pp.22-30.

Minkman, E., Rutten, M., \& van der Sanden, M. (2016). A Q methodological approach to identify practitioners' viewpoints on citizen science in Dutch regional water resource management. Hydrology and Earth System Sciences Discussions, 1-21. https://doi.org/10.5194/hess-2016-26

Mrtek, R.G., Tafesse, E., \& Wigger, U. (1996). Q-methodology and subjective research. Journal of Social and Administrative Pharmacy, 13(2), 54-64.

MSLGROUP PBJS. (2015). The Luxury Consumer Has Evolved. Millennials \& the New Luxury. Retrieved 4 August, 2016, from https://www.slideshare.net/PBJS/millennials-the-new luxury/5THE_LUXURY_CONSUMERHAS_EVOLVED_FROM5HIGHNETWORTHINDIVIDUALSHE NRY

Nielsen, J. (2000). Designing web usability: The practice of simplicity. Indianapolis, IN: New Riders Publishing.

Okonkwo, U. (2007). Luxury fashion branding: trends, tactics, techniques. Palgrave Macmillan, Hampshire, pp.1-332.

Pappas, N. (2016). Marketing strategies, perceived risks, and consumer trust in online buying behaviour. Journal of Retailing and Consumer Services, 29, 92-103. https://doi.org/10.1016/j.jretconser.2015.11.007

Parisi, D. (2017, October 18). Older consumers just as likely to shop luxury online as millennials. Luxury daily. Retrieved from https://www.luxurydaily.com/older-consumers-just-as-likely-to-shop-luxury-online-as-millennials/

Pew Research Center. (2017, Spring). Global Attitudes Survey. U.S. data from a Pew Research Center survey $\begin{array}{lllll}\text { conducted } & \text { Jan. } & 3-10, & \text { Retrieved } & \text { from }\end{array}$ http://www.pewinternet.org/dataset/jan-3-10-2018-core-trends-survey/

Pham, D.D. (2017). Factors influencing young Vietnamese people's decision when choosing luxury fashion online stores. Bachelor's Thesis, Turku university of applied sciences. Retrieved from http://www.theseus.fi/handle/10024/132340

Previte, J., Hearn, G., \& Dann, S. (2001). Profiling Internet user's participation in social change agendas: An application of Q-methodology. Paper presented to the $29^{\text {th }}$ research Conference on Communication, Information and Internet policy, Australia. Retrieved from http://arxiv.org/ftp/cs/papers/0109/0109058.pdf

Quintavalle, A. (2012). Retailing in the luxury industry. In Hoffmann, J. \& Coste-Maniere, I. (Eds.), Luxury Strategy in Action (pp.74-107). Basingstoke: Palgrave Macmillan.

Rajé, F. (2007). Using Q methodology to develop more perceptive insights on transport and social inclusion. Transport Policy, 14(6), 467-477. https://doi.org/10.1016/j.tranpol.2007.04.006

Ramlo, S.E. (2015). Q methodology as a tool for program assessment. Mid-Western Educational Researcher, 27(3), 207-223. Retrieved from https://eric.ed.gov/?id=EJ1071850

Rohm, A., \& Swaminathan, V. (2004). A typology of online shoppers based on shopping motivations. Journal of Business Research, 57(7), 748-757. https://doi.org/10.1016/s0148-2963(02)00351-x

Smith, C. (2015, April 27). Gen X and baby boomers present a huge opportunity for online retailers. Retrieved 17, October 2018, from https://www.businessinsider.de/the-age-demographics-of-who-shops-online-and-on-mobile-2015-4?r=US\& $\mathrm{IR}=\mathrm{T}$

Song, S., \& Ko, E. (2016). Perceptions, attitudes, and behaviors toward sustainable fashion: Application of Q and Q-R methodologies. International Journal of Consumer Studies, 41(3), 264-273. https://doi.org/10.1111/ijcs.12335

Soopramanien, D., \& Robertson, A. (2007). Adoption and usage of online shopping: An empirical analysis of the characteristics of "buyers" "browsers" and "non-internet shoppers". Journal of Retailing and Consumer Services, 14(1), 73-82. https://doi.org/10.1016/j.jretconser.2006.04.002 
Statistics Korea. (2017, Feb. 3). Media Release: Online shopping annual trends Dec 2016.

Stephenson, W. (1978). Concourse theory of communication, 3, 21-40.

Sulphey, M.M. (2014). The utility of Q-methodology in human resource management research. International Journal of Human Resources Management, 3(3), 15-26. Retrieved from https://www.researchgate.net/publication/306509803

Swarnakar, P., Kumar, A., \& Kumar, S. (2016). Why generation Y prefers online shopping: a study of young customers of India. International Journal of Business Forecasting and Marketing Intelligence, 2(3), 215-232. https://doi.org/10.1504/ijbfmi.2016.078604

The Economist (2014). Marques for Millennials. Young people choose and buy differently. Retrieved 4 August, 2016,

http://www.economist.com/news/special-report/21635762-youngpeople-choose-and-buy-differently-marqu es-millennials

Valkama, S. (2015). The News Consumption of Digital Natives (Unpublished master's thesis). UNIVERSITY OF JYVÄSKYLÄ School of Business and Economics. Retrieved 17 October, 2018, from https://jyx.jyu.fi/handle/123456789/48373

Van Exel, J., \& de Graaf, G. (2005). Q methodology: A sneak preview. Retrieved from http://qmethod.org/articles/vanExel.pdf

Watts, S., \& Stenner, P. (2012). Doing $Q$ methodology: theory, method and interpretation. London: Sage Publications.

Watts, S., \& Stenner, P. (2014). Doing $Q$ methodological research. Los Angeles [etc.]: Sage Publications.

Whang, S.M., Yoo, S.W., \& Chon, H.W. (2013). A study on the types of Luxury consumption in Korean society. Journal of KSSSS, 27, 97-111.

Wiedmann, K., \& Hennigs, N. (2013). Luxury marketing, pp. 207-219. Wiesbaden: Springer Gabler.

Williams, E. (2018). Generation X Consumer Behavior. Retrieved 17, October 2018, from https://yourbusiness.azcentral.com/generation-X-consumer-behavior-9585.html

Wu, M., Chen, C., \& Chaney, I. (2013). Luxury brands in the digital age - the trust factor. In Wiedmann, K., \& Hennings, N. (Eds.), Luxury Marketing. Gabler Verlag: Wiesbaden. https://doi.org/10.1007/978-3-8349

Yazici, B. (2016). Attitudes of generation Y towards luxury products and youth-led change in luxury consumption behaviour. The Turkish Online Journal of Design, Art and Communication, 6(3), 291-306. https://doi.org/10.7456/10603100/001

\section{Copyrights}

Copyright for this article is retained by the author(s), with first publication rights granted to the journal.

This is an open-access article distributed under the terms and conditions of the Creative Commons Attribution license (http://creativecommons.org/licenses/by/4.0/). 